This is a so-called personal version (author's manuscript as accepted for publishing after the review process but prior to final layout and copyediting) of the article.

Risberg, A., Tienari, J. and Vaara, E. Making sense of a transnational merger: Media texts and the (re)construction of power relations. Culture and Organization, 2003, 9(2), 121-137.

Researchers are kindly asked to use the official publication in references.

\title{
Making Sense of a Transnational Merger: Media Texts and the (Re)construction of Power Relations
}

\author{
ANNETTE RISBERG \\ Copenhagen Business School \\ JANNE TIENARI \\ Lappeenranta University of Technology \\ EERO VAARA \\ Ecole de Management de Lyon
}




\begin{abstract}
In this study of symbolic power relations in a transnational merger, we suggest that the popular media can provide a significant arena for (re)constructing national identities and power in this kind of dramatic industrial restructuring, and are an under-utilized source of empirical data in research studies. Focusing on the press coverage of a recent SwedishFinnish merger, we specify and illustrate a particular feature of discursive (re)construction of asymmetric power relations; superior (Swedish) and inferior (Finnish) national identities, which, we argue, are embedded in the history of colonization and domination between the two nations. The findings of the present study lead us to suggest that a lens taken from postcolonial theory is particularly useful in understanding the wider symbolic power implications of international industrial restructuring.
\end{abstract}

Key words: National Identity; Power Relations; Media; Merger; Colonization 


\section{INTRODUCTION}

Mergers and acquisitions are of perennial interest in organization and management studies. In addition to the traditionally dominant strategic perspective (Haspeslagh and Jemison, 1991), these dramatic organizational and industrial restructurings have been studied from human resource and cultural perspectives (Buono and Bowditch, 1989; Nahavandi and Malekzadeh, 1988). Further, as mergers and acquisitions across national borders have become increasingly popular, cross-cultural studies have also looked at transnational mergers from the perspective of national culture (Calori et al., 1994; Very et al., 1998; Lubatkin et al., 1998; Olie, 1994; Søderberg and Holden, 2002). However, much of the culture-oriented literature in this field has been based on an essentialist conception of culture and has focused on cultural differences, distance and compatibility, without taking broader questions of identity and power seriously (Vaara, 1999).

Nevertheless, the ramifications of major mergers transcend the boundaries of the focal organizations involved (Vaara and Tienari, 2002). This is because issues such as location of headquarters, choice of top management teams, division of roles and responsibilities, allocation of resources and decisions concerning layoffs and shutdowns have direct or indirect effects on a variety of stakeholders. The symbolic power implications of transnational mergers in particular can, however, be far greater than any traditional organizational stakeholder analysis would imply. Organizational and national identitybuilding processes involved in making sense of the implications of such mergers are complex.

In this article, we examine the ways in which symbolic power relations between social actors are discursively produced in a transnational merger. Our starting point is to focus on the discursive construction and reconstruction of social identities (Davis, 1983; Brown 2001). We are in particular interested in the (re)construction of national identities and the social dispositions and structures of domination associated with these identities (Clegg, 1989). Subjectively construed identities are in this sense power effects, which are articulated in mundane everyday language use (Billig, 1995; De Cillia et al., 1999). 
The popular media which address relational issues, differences and comparisons, are a significant empirical context for the discursive construction of national identities around the event of a transnational merger. Due to their significance and often dramatic appearance, mergers and acquisitions typically attract considerable amounts of media coverage, becoming something of a spectacle. The growing influence of media in the contemporary "global" world has been subject, for example, to sociological (Bourdieu, 1998a, 1998b) and critical linguistic (Fairclough, 1995, 2000; Chomsky, 1999) attention. There has thus far, however, been less interest on media and media texts in the field of organization theory and management studies (see, however, Mazza and Alvarez, 2000; Vaara and Tienari, 2002; Hellgren et al., 2002).

The empirical focus in this article is on the merger between Nordbanken (Sweden) and Merita Bank (Finland), which was announced in October 1997. At the time, it was the largest merger ever to take place between a Swedish and a Finnish company, as measured in terms of personnel and turnover. Especially at its outset, the making of Merita-Nordbanken attracted a great deal of media attention in both countries. ${ }^{1}$ In this article, we analyze the Swedish and Finnish press coverage of the merger by using the methods of critical discourse analysis (Fairclough, 1997). Our study illustrates the importance of media discourse in constructing and reconstructing national identities with specific power implications for organizations. ${ }^{2}$

\footnotetext{
${ }^{1}$ The geographical expansion strategy of the owners and executives in Merita-Nordbanken materialized when they announced a merger with the Danish Unidanmark in March 2000. The strategy was further strengthened through the acquisition of the Norwegian Christiania Bank og Kreditkassen in Autumn 2000. The Nordic financial services group is now called Nordea.

${ }^{2}$ Sweden and Finland share a common history. Already in 1150, King Erik of Sweden led a crusade to what is today the southwestern part of Finland. From the peace treaty of 1323 until 1809, Finland was a Dukedom in the Kingdom of Sweden. In 1809, Finland was incorporated as a Grand Duchy within Imperial Russia. In 1917, Finland for the first time gained its independence. As a consequence of Swedish influence during the period of colonization, the Swedish legal and social system took root in Finland. Also, there is still today a Swedishspeaking minority in Finland, amounting to approximately six percent of the population. The Swedish-speaking minority has been extremely influential in, for example, the domains of culture and business in Finland, and the Finnish-speaking majority has generally regarded it as an elite. Alongside Finnish, Swedish remains an official language in the country. Consequently, it is obligatory for all Finnish-speaking school children to study a certain amount of Swedish at school. Obligatory Swedish remains a contested topic in Finland.
} 


\section{NATIONAL IDENTITIES, POWER RELATIONS AND MEDIA TEXTS}

The notion of social identities rests on the understanding that people define themselves as members of social collectives and categories (Tajfel and Turner, 1979; Turner, 1985; Ashforth and Mael, 1989). Identity building is a core preoccupation in sensemaking (Weick, 1995) where actors develop representations of the self (and others) in relation to others (and themselves). The "social" identities of individuals are embedded in social relations. Identity building is also situation-specific as images of self are constructed in relation to particular others, making sense of new situations where the other is involved. A sense of community within a collective becomes mediated through symbols and rituals in these situations, drawing upon discursive resources. Identities are thus not fixed, stable attributes. Individuals aiming at distinguishing themselves from others constantly redefine their identities (Czarniawska, 1997). Constructed identities can often be temporary, ambiguous and even conflicting.

In this study, we explore power relations and (national) identities in the context of popular media, concentrating especially on understanding the "wider" circuit of power (Clegg, 1989). We consider subjectively construed identities as power effects, complex outcomes of processes of subjugation and resistance that are contingent and perpetually shifting (Clegg, 1994, cited in Brown 2001). Identity is a power effect as it reflects and reconstitutes broader discourse defining and redefining social dispositions and structures of domination, here, in terms of "nations" and national collectives (cf. Clegg, 1989).

Some social categories and categorizations with which individuals aim to be identified are relatively stable. A particular national collective is arguably one (for us, "nation" is a cultural construct rather than a political one). Nationalism depends on a set of deeply held images of historical time and community. Narratives of origin and destiny are central for the discursive construction and reconstruction of nationalism. Anderson (1983) talks about imagined, "invented" histories of nationalism. Peoples' imaginations are constantly fed. Notions of nationalism and national identity have experienced a revival as a means for researchers toattempt to make sense of contemporary large-scale social changes (Lyons and Breakwell,1996). 
National identities are discursive constructs (cf. De Cillia et al., 1999). Billig (1995) uses the concept of banal nationalism to refer to the ways in which the construct of nation is often accepted and reproduced mindlessly and uncritically in everyday talk, rendered possible by mundane habits of language, thought and symbolism. De Cillia et al. (1999: 153) provide an illustration of how "national identities are discursively, by means of language and other semiotic systems, produced, reproduced, transformed and destructed". Narratives and identities, however, do not emerge from nowhere, and they do not operate in a vacuum. The construction and reconstruction of national identities involves a multifaceted process of linking contemporary events with existing cultural conceptions (Fiske, 1989a). If we accept that these conceptions are historically formed and reflecting broader discourses (re)defining symbolic structures of domination, a post-colonial theoretical lens may prove useful in understanding identities and the "wider context" and (symbolic) power relations (Prasad, 1997) in, for example, contemporary transnational mergers. Relations between particular peoples or "nations" may in this way be conceptualized to resemble a post-colonial condition (Said, 1995).

National identification in media discourse is the empirical focus of this article. The media have assumed a central role in contemporary societies. Politics, economy and business are examples of arenas where media are extremely influential (Fairclough, 1995, 2000). This means among other things that journalists create images that in turn may shape public views on the phenomena reported and commented upon. The media make sense of "realities out there" - and give sense and meaning in reporting and commenting upon these realities for their audiences (Fiske, 1989b; Gioia and Chittipeddi, 1991; Weick, 1995). The media represent and reproduce particular versions of "reality"; promoting particular voices and marginalizing and excluding others (Vaara and Tienari, 2002). The media also contrast different voices in texts to create what they consider will appeal to their audiences as good stories. This is one of the classic tricks of the trade, of which identifying "winners" and "losers" or heroes and scapegoats is an example (on top managers' own stories and narratives of mergers, see Vaara, 2002).

Journalists place their topics into specific discursive frames. This takes place under continuous pressure for space and time, where choices have to be made. In such a position journalists often reproduce commonly held views, for example, building on stereotypes. Limited space means that individual texts have to be as compressed as possible. On time 
pressures of journalists, Bourdieu (1998a) writes that journalists "think in clich'es, in the 'received ideas' that Flaubert talks about - banal, conventional, common ideas that are received generally" (1998a: 29). In other words, journalists write what everybody already knows, and what they expect journalists to write. Bourdieu (1998a) calls these commonplaces, which work because everyone can ingest them immediately and their very banality makes them something the speaker (journalist) and the listener (reader) have in common.

Commonplaces are a part of the framing in media work. If the journalist chooses to frame the story with what everybody already knows, s/he reduces the uncertainty of how the story will be received and interpreted by the reader. In our view, there is an obvious link between commonplaces and banal, mundane ways of (re)constructing national collectives (cf. Billig, 1995; De Cillia et al., 1999). Working on national sentiments and stereotypes may be tempting for journalists in covering dramatic events such as a cross-border merger. The media can be effective in reinforcing national representations and stereotypes in a context in which its unconstraint may otherwise be challenged. Brookes (1999) provides an excellent example of this in his analysis of the British press coverage of BSE - "mad cow disease".

Further, it should be noted that media texts have power implications in the sense that they determine what view of the world - or versions of reality - will be presented to the public. According to Fiske (1989b) news as knowledge creation is power. He specifically refers to two aspects: "The power of knowledge has to struggle to exert itself in two dimensions. The first is to control the 'real', to reduce reality to the knowable, which entails producing it as a discursive construct whose arbitrariness and inadequacy are disguised as far as possible. The second struggle is to have this discursively (and therefore socio-politically) constructed reality accepted as truth by those whose interests may not necessarily be served by accepting it” (Fiske, 1989b:149-50).

The power of media over national identifications amongst its audiences is worth considering. The media may be an important source of support when people seek to justify their picture of self and the other (Weick, 1995; Garfinkel, 1967). For example, members of a merging organization may have a particular view of the other organization and then start to look for evidence in the media coverage in order to justify this view in the merger setting, which is marked by uncertainty (Frommer, 2001; Risberg, 2001). 
Taking into account the apparent influence and power of the media in contemporary societies, and the popularity of mergers and acquisitions in business life, it is surprising how relatively little academic work has been published on the role of the media in the construction of these dramas. There are, however, some notable exceptions. Hirsch (1986) examined corporate takeovers as instances of cultural framing and institutional integration. He specified ideologies, genres and metaphors found in media texts concerning hostile takeovers, and illustrated how particular ideas on these events become legitimized and institutionalized. Schneider and Dunbar (1992) analysed the meanings ascribed to hostile takeovers using a psychoanalytical perspective, proposing a classification according to which most of these dramas can be interpreted as takeovers for growth, control, dominance or synergy. Hellgren et al. (2002) studied how specific issues are constructed in media texts on a transnational merger through interpretations of "winning" and "losing". They distinguished specific discursive practices in how this is accomplished in the texts; factualizing, rationalizing and emotionalizing.

In a discourse analysis of media texts on mergers, Vaara and Tienari (2002) identified four specific discourses, which they labelled as rationalistic, cultural, societal and individualistic. The rationalistic discourse constructs organizational change based on managerial concerns about competitiveness and rationalization (building its legitimacy on economic and financial rationale). This discourse, resembling the mainstream business rhetoric, dominates in the media in two ways; first, it is the only discourse in a large part of the texts, and second, it more often than not occupies a central role in individual texts where other discourses can be identified. Most relevant for the framework in the present paper, the "cultural" discourse specified by Vaara and Tienari (2002) is characterized by confrontation at organizational and national levels. Within this discursive framework, mergers are discursively constructed as confrontations between "us" and "them" (for the readers to identify with). In brief, the media texts both construct (national) identities and reflect commonly held stereotypes of self and the other. 
In the following, we present our interpretation of the discursive (re)construction of symbolic power relations in the merger between Nordbanken (Sweden) and Merita Bank (Finland). The discussion with textual examples taken from Swedish and Finnish press material is based on a comparative study of national identification using critical discourse analysis methods (Fairclough, 1997). ${ }^{3}$ The identities (re)constructed are embedded in the history of domination between the two nations. This shared history becomes activated in making sense of, and giving sense to, the contemporary business event.

\section{MAKING SENSE OF A TRANSNATIONAL MERGER}

A holding company was established when Nordbanken (Sweden) and Merita Bank (Finland) merged. In this holding company Nordbanken's shareholders held 60 percent and Merita's 40 percent of the stock. The voting rights, however, were divided equally between the owners of Nordbanken and Merita. The making of Merita-Nordbanken was thus launched as a "merger of equals". Both banks were products of earlier domestic mergers and acquisitions (see e.g.,

\footnotetext{
${ }^{3}$ Methodological note. The present research comprises a detailed analysis of media texts. Our point of departure is that all texts are "incomplete" and should be studied intertextually (Fairclough, 1997; Grant, Keenoy and Oswick, 1998). This implies that meaning is constructed when the reader-interpreter connects the text to another domain of meaning, text or context. Moreover, we assume that interpretations of media texts are constructed at the very moment the text is read. In this process of sensemaking, the reader is using what is already "known" to him or her. This process is firmly linked with identity building, which implies that the sensemaking process temporarily produces or reproduces the reader's identities.

Our focus is on the first six months of the merger between Nordbanken (Sweden) and Merita Bank (Finland), with a special emphasis on the two-week period following the initial merger announcement. In some instances in the following sections of this article we refer to texts outside our primary material in order to illustrate our points. Our basic Swedish material comprises a total of 79 texts in (1) Dagens Nyheter, a leading daily newspaper, (2) Aftonbladet, the leading tabloid, (3) Dagens Industri, the leading daily business newspaper, (4) Veckans Affarer, the leading weekly business magazine, and (5) Aff arsv"arlden, the leading monthly business magazine. Our Finnish material comprises a total of 84 texts in (1) Helsingin Sanomat, the leading daily newspaper, (2) Ilta-Sanomat, the leading tabloid, (3) Kauppalehti, the leading daily business newspaper, and (4) Talousel"am"a, the leading weekly business magazine. In sum, our material includes all relevant nationwide printed media in the two countries (apart from the second largest tabloids and, in the Swedish case, the newspaper Svenska Dagbladet).

What we offer in this article is our construction of the constructions present in media texts (cf. Thomas and Linstead, 2002). In our analysis, we first identified characteristic themes in the Swedish and Finnish sets of texts respectively. We then focused specifically on texts that seemed to be built upon organizational and national contrast and confrontation. We then moved on to locate ways in which these texts framed and constructed the cross-border merger. Next, we read closely those individual texts and excerpts that seemed to adequately illustrate commonplaces (cf. Bourdieu, 1998a) that journalists use when linking the Merita-Nordbanken merger to the historical legacies of the two nations involved. Some of these illustrative texts are presented and discussed in this paper. Finally, an important part of our intertextual reading of the media material was also reflection on what was left "unsaid", that is, what could already be taken-for-granted by the Swedish or Finnish readers or what was not acceptable to express explicitly in the present context (cf. Fairclough, 1997). In all, the interpretations put forth have been reached through intensive debates between the authors, including careful rereadings of the original texts.
} 
Tienari, 2000). At the time of the merger in October 1997, Nordbanken's market value was approximately 5.80 billion euros and Merita's 3.36 billion.

Managerialist discourse reporting and commenting upon financial and economic rationale through themes such as efficiency and competitiveness has been identified as the typically dominant discursive framework in the context of mergers and acquisitions (Vaara and Tienari, 2002). A large number of the Swedish and Finnish media texts on the Merita- Nordbanken (MNB) merger drew on such rationalistic, managerialist discourse. In the following, however, we concentrate on illustrating and specifying how power relations between the two "national parties" were produced in the media, and how particular national identities are constructed. In general, what we discovered was that in the Swedish texts, cultural discourse (i.e., discourse building on notions of "us" and "them") was usually firmly embedded within a rationalistic frame. In the Finnish texts, cultural discourse framing the merger as national and organizational confrontation with, for example, frequent direct references to the historical relationship between the two "nations" emerged as a distinctive alternative for the rationalistic discursive framework.

\section{Constructing a Superior Swedish Position}

In the Swedish press coverage of the merger, a context-specific superior Swedish symbolic power position and collective identity vis-`a-vis Finns was (re)constructed. Our first example is from a text in Aftonbladet, a major tabloid. Mr. Jacob Palmstierna, the former chairman of the board of Nordbanken and the newly appointed vice chairman of Merita-Nordbanken, was interviewed immediately after the merger had been announced (Palmstierna's comments are in italics):

\section{No, We Never Sat in the Sauna}

Merita does not really sound like the name of a large glorious bank. It sounds more like a hairdressers in Bandhagen. [...] But can you trust it?

- Yes, I can without a trembling voice say that Merita is a bank to trust.

And the new president is Vesa Vainio. That sounds like a snake. [. . .]

- Us Swedes, we've always had warm feelings for the Finns. More so, perhaps, than the other way around.

Why is that? 
- The Finns have always had a big brother complex.

When it is time to gather the board of the new giant bank and sit down for a conference, which language will you use?

- The company language is Swedish. That has been decided on.

You and Vesa Vainio will alternate as chairman every second year. Why? [...]

- This construction is just a way to handle this national issue, as you understand.

No.

- I am speaking about psychology. This merger is an enormous thing to Finland. Merita is their largest, leading bank. For the merger to become accepted in Finland, one must have some balancing factors. One of those is the 50-50 voting rights, another is 5-5 on the board and another is that the chair of the president is alternated.

When did the [merger] negotiations end?

- At two o'clock last night, when we wrote the last comma. There were four of us. Hans Dalborg, Vesa Vainio, Timo Peltola and myself.

Where were you?

- At Palace Hotel in Helsinki, in an ordinary conference room. We celebrated with a glass of beer.

Beer! Shouldn't it be Kosken on a night like this?

- Well, I guess it should. But now it was beer.

But you blessed the deal with a sauna, didn't you?

- No, absolutely not.

[Aftonbladet, October 14, 1997 (Italics ours)]

We can only speculate whether the journalist in Aftonbladet is consciously provoking Mr. Palmstierna as an individual, merely playing a game in bringing up national stereotypes to write up a good story for a Swedish audience or whether he is being "serious". In any case, the title "No, We Never Sat in the Sauna" already frames the text in a particular way, equating Finnishness with a tendency to bathe in the sauna. It thus complies with a well-known stereotype. Further, it is interesting that many of the Swedish stereotypes of Finns activated in the text above are explicitly prejudiced. For example, Finns are associated with working class suburbs of Stockholm, such as Bandhagen (the name Merita sounds "like a hairdressers in 
Bandhagen"). This association is, in fact, not insignificant as there is a large Finnish working class minority in Sweden as a result of migration in the 1960s and 1970s, and a lot of ethnic Finns do live in Bandhagen.

The journalist also brings up the issue of Swedes not being able (or bothered) to pronounce and spell Finnish names correctly, and their tendency to joke about Finnish names in a condescending way. For example, Vesa Vainio (former CEO of Merita) "sounds like a snake". Further, Finns are also represented in the text as heavy drinkers. "Kosken" is an emblem of this. Koskenkorva is a typical Finnish brand of vodka-type strong alcohol. In Swedish everyday language the difficult name is often shortened to Kosken (which is incomprehensible in the Finnish language). For many Swedes, the text may bring into mind previous media coverage of violent crimes committed by (working class immigrant) Finns under the influence of alcohol in Sweden. In all, a relatively barbarian picture is painted of Finns in the text. Conversely, Swedes clearly occupy a superior position vis-`a-vis Finns.

In the text, the interviewee Mr. Palmstierna is represented as the fair chairman who is well aware of potential conflicts in dealing with Finns. Yet, he too produces an image of Swedish superiority in his comments. On the basis of this particular text, Swedish readers are inevitably left with the understanding that the merger is crucial for Little Finland, while in Big Sweden this is a more minor issue. The equal distribution of votes, the building of the board of directors on the basis of national equality, and the alternating chairmanship are just some solutions to calm down the nationalistic emotions of the Finns. It is interesting that Mr. Palmstierna explicitly refers to the Big Brother - Little Brother setting in the present context (note that "Big Brother" does not refer here to the Orwellian idea of a control society). "The Finns have always had a big brother complex". This can be seen as a sign of cultural sensitivity but it can also be interpreted as an act of institutionalization of the superiorityinferiority relationship. It may be interpreted as patronizing. And "us Swedes" is in the text, too, measured against the Finns (cf. Billig, 1995).

It is important to bear in mind that the text deals with top managers' negotiations leading to a major transnational bank merger. Talking about "snakes" and making degrading references to "sauna" and alcohol consumption are thus particular choices made by the journalist. These choices are available to the journalist (and his audience) only due to the specific nature of the Swedish-Finnish relationship in general. The symbolic structure of domination overarching 
the relationship enables the discursive construction of a particular Swedish identity in this situation.

Construction of superiority and inferiority through the use of cultural stereotypes was by no means restricted to the genre of tabloids. An interview with Mr. Hans Dalborg, the former CEO of Nordbanken and the newly appointed CEO in Merita-Nordbanken, published in Veckans Aff'arer, the leading business weekly in Sweden, exemplifies this. The text is titled "It is I who Decides". In the first part of the interview Mr. Dalborg makes it clear, arguing for the rationale of the merger, that "his sole task is to money for the shareholders". The text then seems to change gear (Dalborg's comments in italics):

Hans Dalborg is of the opinion that in Sweden we have not really understood how important this deal is in Finland, where Merita is the national bank before others. Sweden has four large banks of rather equal size, but Finland only one that now gets 60 percent Swedish ownership. It is a dramatic step. Moreover, Merita, with its parts from Kansallis and the Union Bank of Finland, is more than a bank. It is by tradition a great power player in Finnish economic life with a number of shares and personal connections to leading Finnish companies. It is said about the previous CEO of Kansallis that he was on the board of so many companies, some thirty, that it was well understood why he didn't have time to manage the bank. But the new CEO will not be inspired by his example.

- I am not interested in the Finnish power game - Vesa Vainio will have to take care of that. My only goal is to make money for our owners by increasing the profit per share.

But, will your role as a despotic CEO not become extremely limited? The representation on the board is half each from the Swedish and the Finnish side.

- This is not a conglomerate, this is a bank, with one management. The new management knows of no national borders and will be in charge for both the Swedish and the Finnish business. It is accepted that the top management of the company group that makes the decisions is large. If we agree, there is no problem, if we disagree, I make the decisions. 
So you will perform some Finnish authoritative leadership style?

- In Nordbanken there are no limitations to what you are allowed to say, as long as the door to the outside is closed. But when the CEO has made the decision one will go out and implement it even though one disagrees. This model will work here too, I'm convinced about that.

[Veckans Aff'arer, October 27, 1997 (Italics ours)]

This text is not only interesting because of its provocative title. It illustrates how nationalistic sentiments intertwine with the dominant rationalistic discourse in the Swedish press coverage of the merger. Underlying the reported dialogue between Mr. Dalborg and the journalist is the association of rationalism with Swedishness. Construction of Swedish superiority is most clearly shown in the rendering of Mr. Dalborg's seemingly patronizing attitude towards the "Finnish power game". He (as the Swede in control) stands above that game, but will let the (emotional) Finns continue with it if they wish to do so. It is evident in the way the text is constructed that there are no unnecessary power games in Sweden.

There is also a hint that if the problems created by the "Finnish power game" would require tough actions, Hans Dalborg (i.e., as the CEO and a Swede) will have the final word. Rest assured, Swedish audience. Finally, the journalist's immediate association of "I make the decisions" (in Dalborg's remark) with "Finnish authoritative leadership style" is notable. This calls for more justification in the text from Mr. Dalborg who makes it clear that the archetypal Nordbanken (Swedish) management model - "there are no limitations to what you are allowed to say, as long as the door to the outside is closed" - will prevail; "this model will work here too". In all, the structure of domination overarching the Swedish-Finnish relationship enables the journalist (and the interviewee) to discursively construct a particular Swedish identity; the rational self as opposed to the emotional other. ${ }^{4}$

Finally, a less subtle example of Swedish superiority constructed in the Merita-Nordbanken merger. This is found in an article in Dagens Industri, the major Swedish daily business

\footnotetext{
${ }^{4}$ Similar discursive constructions seem to have emerged in relation to other transnational mergers. The aborted merger between the state-owned telecommunications companies Telia (Sweden) and Telenor (Norway) provides an example. The merger agreement was already negotiated, but widely publicized power struggles between the "national sides" in the early implementation phase led to the cancellation of the deal.
} 
newspaper. The "Finnish authoritative leadership style" is expressed through another kind of vocabulary:

\section{The End of Management by Perkele}

Finnish managers are listening to their employees.

A wind of change has blown over the industrial life and its outstanding figures in Finland. Whisky and cigars in dim lighted cabinet rooms are out and management by perkele belongs to the past. [. . .] The new generation of Finnish managers are taking care of their health, playing ball with their children and demanding an open dialogue with their subordinates. And little by little they are beginning to learn about openness; press conferences are no longer arranged for the top management to show off and glitter; now it is about answering questions as far as possible. Jorma Ollila, the CEO of Nokia, is leading the development. He has managed to implement a totally new corporate culture among his employees (Dagens Industri, November 20, 1997).

Many readers of Dagens Industri are likely to recognize the Swedish stereotype of Finnish management style, coined in the Finnish swearword perkele ("devil"). "Management by perkele" is a term that became famous in Sweden in the mid-1980s when Finnish companies started to acquire companies in Sweden. The Swedish employees, apparently used to dialogue between managers and employees, were said to be shocked by what they considered as ruthless and authoritarian management style by Finnish managers (Laine-Sveiby, 1987, 1991; Ekwall and Karlsson, 1999). The tone in the text above indicates, then, that the Finnish managers are now making progress as they are working for "open dialogue" and "little by little they are beginning to learn about openness". What is interesting here is that this progress is described as moving from the stereotypical Finnish management style as perceived by Swedes towards the archetypal Swedish style characterized by egalitarianism, co-operation and consensus seeking; i.e., the "open dialogue" (Ekwall and Karlsson, 1999; Zander, 1999; Berglund and L“owstedt, 1996). For a Swedish audience, the obvious underlying message in the text is that the Finns are now "little by little" reaching a more 
advanced stage in management and managing which Swedes have mastered for quite some time. $^{5}$

Why the particular discourse in the Swedish media? In commenting upon the merger between Nordbanken and Merita, the general tone in the Swedish press coverage seems to have moved from critical to neutral. Arguably, (re)constructing symbolic power relations between nations became necessary, because when the terms of the "merger of equals" were first made public, it seemed that the Finns had lured the Swedes in the merger negotiations (as pointed out above, Nordbanken's market value was approximately Expensive experiment", and the text made it clear that "doubtful motives and weak arguments" characterize the merger. Dagens Industri claimed already on October 14, 1997, that "the merger does not create any value added for Nordbanken's shareholders".

After the merger announcement, CEO Hans Dalborg in particular held the role of justifying the rationale of the merger to the Swedish public through the popular press. After the initial criticism in the media, Mr. Dalborg seems to have carried out the justification work well. The representations of the financial rationale of the merger between Nordbanken and Merita shifted over time in the Swedish press. Veckans Aff'arer (April 27, 1998), for example, writes that merging with Merita may be viewed as positive for the Swedish shareholders in the long run. To put it provocatively, Swedish journalists were now able to conclude that Swedish rationality eventually prevailed in the merger.

\section{Constructing an Inferior Finnish Position}

In the Finnish press coverage of the merger, a context-specific inferior Finnish symbolic power position and collective identity vis-`a-vis Swedes was (re)constructed. Finnish texts swarm with direct references to the historical relationship between the two "nations". This is

\footnotetext{
${ }^{5} 80$ billion euros and Merita's 3.36 billion at the time of the merger). The first reaction in the Swedish media was that the merger was not a good idea; the Swedish taxpayers (the Swedish state was a major shareholder in Nordbanken) and shareholders were portrayed as the losers in the arrangement. With regard to the line-up in top management, the apparent 50-50 balance of power appeared distorted. Dagens Nyheter, a major daily broadsheet, described this as "fairness for the sake of fairness" (October 14, 1997). At the outset, from a "Swedish position" there seemed to be no logical reasoning for the merger. A title in Veckans Aff'arer (October 20, 1997) read "Nordbanken-Merita: 5Swedish stereotyping of Finnish managers as ruthless and authoritarian brings an important difference to the fore. For Finns, these attributes are not necessarily negative. Nokia, the global company with strong Finnish roots, has been used as a positive example of management by perkele, which is depicted as flexible "guerrilla warfare" style management with quick decision making well suited to the increasingly fast-moving global world of business; "there is readiness to confront change" (Bruun and Wall'en, 1999).
} 
illustrated by the following excerpt from a column by a well-known Finnish business journalist commenting on the reactions of the Swedish media immediately after the merger announcement:

[...] The joy of the former eastern provinces of the Swedish Empire is made complete by the initial comments from Stockholm. Dagens Industri, always so convinced of the excellence of the Swedes, turned up its nose at Nordbanken, and the rest of the press wasn't exactly applauding the first Swedish-Finnish union in the financial world.

(Helsingin Sanomat, October 20, 1997)

From 1323 to 1809 , Finland was colonized by the Kingdom of Sweden. It is apparent in the above text that the journalist is building on the notion that the Little Brother has come back to the Big Brother; "the joy ... is made complete". Interestingly, in the original Swedish text (in Dagens Industri, the business daily) the case was framed between Nordbanken and Merita, not Sweden and Finland. In the Finnish text, the same case is explicitly presented as one between the former colonizer (the self-promoted "excellent" Swedes) and its colony (Finland as "the former eastern provinces" of the colonial state). The historically determined, asymmetric Swedish-Finnish relationship enables the discursive construction of a particular Finnish identity - inferior but resistant - in this situation. This text also brings another aspect of the Swedish-Finnish relationship to the fore; while the Finnish press often commented and reflected on the writings of the Swedish media, the opposite was the case only very rarely.

Inferiority can be read in Finnish media texts through the theme of Swedes abusing or doing injustice to the Finns - and the Finns resisting. This is evident in the curious rhetorical leap made in the following texts. These texts make up an article that was published in IltaSanomat, a Finnish tabloid. Again, the article reflects on the writings of the Swedish Dagens Industri, where a Swedish board member in MNB had been interviewed some time earlier:

\section{A Wild Swedish Estimate: Merita to Cut Down its Personnel by as Much as 4000}

Suspicion about the bank merger taking the bread out of the mouths of thousands of Merita's employees gets reinforcement from Sweden. Rune Brandinger, a board member in Merita-Nordbanken, promises that a lot of cost savings are due on the 
Finnish side. According to Dagens Industri, the paper that interviewed Brandinger, the reduction in Merita will be 3000-4000 people within a period of 3-5 years.

\section{Merita's Pertti Voutilainen: Brandinger is Not Acquainted with the Matter}

[. . .] Is it bitterness related to ice hockey that is behind all this? The story in Dagens Industri was published the same day as the Swedish tabloids, bitter from their defeat in ice hockey, were abusing Finland. Could Brandinger's comment be related to bitterness in hockey? - I suppose not, Voutilainen remarks. - Coincidentally, I was in Stockholm on Wednesday when the result [of the ice hockey match] came out, and we thought that although there are no international matches in MeritaNordbanken, we'd allow this external one. - Let's enjoy this [victory] now, and they [i.e., Swedes] can be ashamed of being worse than we [i.e., Finns] are in ice hockey.

[Ilta-Sanomat, February 20, 1998 (Italics ours)]

With ice hockey, the journalist refers to the quarterfinal match between Sweden and Finland in the 1998 Olympics in Nagano. Finland beat Sweden 2-1 and made it to the semifinals. Pertti Voutilainen is the former CEO of Kansallis. At the time of the interview, he was a member of the board of Merita-Nordbanken. The explicit reference to sport as a domain of confrontation between Sweden and Finland is here especially intriguing. It has recently been argued that sport continues to be a marker of distinctive cultural and national identities in a "global” world (Boyle and Haynes, 1996). Sports journalism produces a turn inwards toward national concerns, and a buttressing of a sense of difference (Blain et al., 1993). What is interesting in our press material is that Finnish journalists seem to draw on sport precisely in this way when commenting on a business manouver, bringing an emotional flavour to it.

Sport in general has played a major role in the construction and reconstruction of national identity in Finland, especially since the declaration of independence in 1917. Competing against Sweden has been particularly important for the buttressing of Finnish national identity in, and through, sports. The rhetoric in the coverage of the Merita-Nordbanken merger brings the sensitivity involved in this to the fore. More specifically, as in the text above, it illustrates how the construction of Finnish national identity is typically defensive in nature, that is, competing from an inferior position vis-`a-vis the other (Sweden). This is illustrated in a 
number of texts in the context of the Merita-Nordbanken merger. Merita is directly equated with Finland: "Finland Loses 6-5 in the Organization Game" (headline in Kauppalehti, October 14, 1997). Other typical examples include: "Nordbanken - Merita 1-O" (headline in Ilta-Sanomat, November 5, 1997), "Business Units: Sweden 3, Finland 2" (sub-heading in Ilta-Sanomat addressing the new organization structure of the bank, December 19, 1997), and "The Score in the International Seems to be 0-1 for the Swedes" (headline in Helsingin Sanomat, October 28, 1998).

Apart from sport, another recurring metaphor in the Finnish press coverage of the MNB merger is war. It is not unnatural for Finns to depict the Finnish-Swedish relationship as an ongoing battle. Although Finns and Swedes have never actually been at war as "nations" due to the long colonial relationship and the immediate passing of Finland into the hands of Imperial Russia in 1809 - this kind of imagery is frequent in the public discussions in Finland. Associations with war and batt, again, enhance an emotional involvement in the SwedishFinnish relations.

In an article titled "A Finnish Counterattack Is Possible", the major Finnish business weekly speculates on possible attempts by Finnish owners "to regain power in MeritaNordbanken to Finland" (Talousel"am"a 35/1997). Further, when Merita-Nordbanken sold its stock in the major Finnish insurance company Pohjola in Janury 1999, commentary on Swedish recolonization of Finland mounted. The buyer was Skandia, the largest insurance company in Sweden. As Pohjola had been a part of the traditional "Fortress of Blue-andWhite Capital" (Helsingin Sanomat, January 17, 1999), a power bloc of Finnishnationalistically minded industrialists and businessmen, the deal evoked comments in a special tone:

\section{The Gate was Opened}

It is hard to describe a big event or feeling. You either hear excess or mundane words. Thursday 4 o'clock p.m. Merita-Nordbanken sold its shares in Pohjola to the Swedish insurance company Skandia. The fortress of the Finnish-nationalistic capital, over a hundred years old, was opened to the Swedes. "Skandia asked for the shares just before Christmas and we answered Skandia's question," Vesa Vainio, the chairman of the board in MeritaNordbanken described the atmosphere after the deal. On May 5, 
1808, vice admiral Carl Olof Cronstedt surrendered Viapori, without notable opposition, to the Russians. [. . . I I admit that the analogy is limping and excessive.

(Helsingin Sanomat, January 10, 1999)

\section{Vesa Vainio is Annoyed of Being Accused of Treason}

(Helsingin Sanomat, January 17, 1999)

Viapori is a fortress on an island off Helsinki. Vesa Vainio (at the time, the vice chairman of the board of MNB) is put into the role of collaborating with the (Swedish) enemy; he is "accused of treason". The journalist above is aware of his particular choice of words - "I admit that the analogy is limping and excessive" - but he has yet found it relevant to activate the war metaphor, drawing upon a collective Finnish memory on the "loss" of the Viapori fortress. "The Gate" which is now "opened" symbolizes in our view Swedish recolonization of Finnish territory.

Further, in the Finnish media coverage of the Merita-Nordbanken merger, language became a particularly clear example of interpreted Swedish victory and (re)colonizing attitude. The laconic comment "The company language is Swedish. That has been decided on" by Jacob Palmstierna in the interview in Aftonbladet (Swedish tabloid) quoted above conceals a complex, sensitive and much-debated question in Finland. The Swedish CEO of MeritaNordbanken, Hans Dalborg, was interviewed in Kauppalehti, the major Finnish daily business newspaper, immediately after the merger was announced. One of the sub-headings in the text was "Does the Spirit of the International Match Live on?". Among other themes, the journalist brought up the issue of language. Dalborg commented, referring to the merger negotiations:

Creating a joint corporate culture is extremely important, Dalborg emphasizes. He says that creating mutual understanding is made easier by the fact that Merita is a completely bilingual bank. According to him, language used in the negotiations has been Swedish all along. [Kauppalehti, October 15, 1997 (Italics ours)] 
We do not know whether these were his "original" words, but Mr. Dalborg is presented in the text as if he believes it to be natural that all Swedes and Finns should communicate in Swedish, just like he had apparently done with Finnish top managers in the merger negotiations. The language question is, however, a highly contested terrain for Finns in general. Over $94 \%$ of the Finnish population do not speak Swedish as their mother tongue, and a large part of the Finnish speakers resent the compulsory Swedish - a remnant of the colonization era - that they are forced to study at school. Depicting Merita as "a completely bilingual bank" then illustrates Mr. Dalborg's ignorance of contemporary Finnish society at the time of the interview.

Some two weeks after Hans Dalborg's interview the decision to root Swedish as the "official corporate language" in Merita-Nordbanken was made public. This language choice was constructed in the Finnish media coverage as an unfair decision creating a great deal of practical problems for the Finnish employees in MNB who were now being forced to use a foreign language in their work. Language was also portrayed to mark a power imbalance in the organization. Vesa Vainio defended the language choice in an interview with IltaSanomat, the leading Finnish tabloid:

\section{Merita Chose Swedish Vesa Vainio: No Way to Management without Language} Skills

When the Finnish Merita and the Swedish Nordbanken merge, the official language in the new bank will be Swedish, the chairman of the board in the new big bank, Vesa Vainio assured yesterday.

According to Vainio, the decisive thing is that the skills of the Swedes in the Finnish language are considerably weaker than the Finns' are in Swedish.

Among the top management in Merita, there have been dreams about English, the one and only international banking language, becoming the final official language in the bank. You can now say goodbye to these dreams.

Vainio said that, in routine work, you could use the local language in both countries. It is no use dreaming to get to the top management in the bank, however, if your 
Swedish isn't fluent. Skills in the Finnish language have, however, not been set as a requirement for reaching the board. . . . (Ilta-Sanomat, October 23, 1997).

The journalist's choice of words is intriguing. English and Finnish as corporate languages are presented as unattainable "dreams". The sarcasm is noteworthy; for example, it is well known among Finns that extremely few Swedes have made the effort of learning the Finnish language. The following text was published in Talousel"am"a almost a year after the interviews in Kauppalehti and Ilta-Sanomat quoted above. Note, again, the explicit link to sports:

The chairman of the board in Merita-Nordbanken, Vesa Vainio, is surprised over the extent of emotional turmoil that Sweden and the Swedish language still provokes among Finns. Nordic mergers and acquisitions are persistently commented upon in the spirit of sports internationals between Finland and Sweden. [. . .] - The issue of language has been more significant than we initially imagined [Talousel"am"a, 27/1998 (Italics ours)].

This is an illustration of how historical legacies live on in everyday life as they are activated in public discussion. Here, the legacy is related to the fact that the Swedish and Finnish languages have continued to structure the Finnish society and economy since the colonization period. In the MNB merger, the Swedish language emerged for the Finnish national collective (as constructed in the media) as a symbol of their asymmetric power relationship with Sweden and Swedes. It emerged as a symbol of recolonization. Further, if we assume that media coverage on the merger between Nordbanken and Merita is part of its public as well as the intraorganisational sensemaking, it can be speculated that when reproduced in the media, underlying images of superiority and inferiority may influence the internal sociopolitical struggles in the merging organizations ${ }^{6}$ and become a self-fulfilling prophecy. Table 1 summarizes key features in the construction of superiority/inferiority in Swedish and Finnish media texts on the studied merger.

\footnotetext{
${ }^{6}$ Based on recent research on the organizing of the Merita-Nordbanken merger, for example, it is evident that the question of Swedish dominance was heatedly debated in the Finnish part of the organization, and the language question in particular triggered non-commitment and resistance among Finnish employees (Vaara et al., 2000; S“antti, 2001). Apparently, when the Danish Unidanmark joined the Merita-Nordbanken group in March 2000, the top management immediately announced that the official corporate language is English.
} 


\section{CONCLUSION}

In this article, we have examined the (re)construction of national identities in the context of a transnational merger. Our critical discourse analysis of media texts has shown how the issues at hand reflect and reconstitute broader discourse defining and redefining social dispositions and structures of domination between particular peoples and "nations". Such analysis of power relations is in our view relevant and timely for mapping out and understanding the complex cultural and political implications of major contemporary industrial restructurings such as transnational mergers.

TABLE 1 Key Features in the Construction of Superiority/Inferiority in Media Discourse

\begin{tabular}{|c|c|c|}
\hline & Superior position & Inferior position \\
\hline Role of nationalistic discourse & $\begin{array}{l}\text { Nationalistic discourse as firmly } \\
\text { embedded within rationalistic } \\
\text { discourse. }\end{array}$ & $\begin{array}{l}\text { - Nationalistic discourse as a } \\
\text { distinctive altemative for } \\
\text { rationalistic discourse. }\end{array}$ \\
\hline Role of legends and myths & $\begin{array}{l}\text { - Lack of references to (nationally } \\
\text { important) legends and myths. }\end{array}$ & $\begin{array}{l}\text { - Frequent references to (nationally } \\
\text { important) legends and myths, } \\
\text { e.g. sports and war metaphors. }\end{array}$ \\
\hline Typical stereotypes & $\begin{array}{l}\text { - Normalized auto-stereotypes. } \\
\text { - Patronizing and belittling } \\
\text { stereotypes of the (emotional) } \\
\text { other. }\end{array}$ & $\begin{array}{l}\text { - National ideals as auto- } \\
\text { stereotypes. } \\
\text { - Envious stereotypes of the other. }\end{array}$ \\
\hline Constructed subjectivity & $\begin{array}{l}\text { - Modern and progressive } \\
\text { subjectivity. }\end{array}$ & - $(\mathrm{Re})$ colonized subjectivity. \\
\hline Constructed dispositions & - Inherent dominance. & - Power/need of resistance. \\
\hline
\end{tabular}

In our study of the Swedish and Finnish press coverage of the merger between Nordbanken (Sweden) and Merita Bank (Finland), the media are understood as sensemakers and sensegivers in their practices of promoting particular versions of "reality" and marginalizing and excluding others (Fiske, 1989b; Gioia and Chittipeddi, 1991; Weick, 1995). National identification provides a discursive platform for the media to make sense of these complex phenomena for the benefit of their audiences (cf. De Cillia et al., 1999). Cultural sensemaking in the form of (re)constructing national identities is an interpretive act which draws from historical legacies; stereotypes, myths and stories in different social domains. It is about constructing and reconstructing "us" and "them" in mundane everyday language use (Billig, 1995), based on these legacies. In the Swedish-Finnish merger, we have specified a particular feature of the discursive (re)construction of asymmetric power relations; superior 
(Swedish) and inferior (Finnish) national identities, which are embedded in the history of domination between the two nations. This shared history becomes activated in making sense of, and giving sense to, the contemporary business event.

The contextual and situation-specific nature of (re)constructing social identities does not mean that the theoretical apparatus put forth in this article cannot be used elsewhere. On the contrary: we talk about Swedes and Finns, but the setting could just as well be Swedes and Norwegians, the English and the Irish, the English and the Scottish or any other relationship between peoples with a shared past of domination and colonization. While national identities (re)constructed in relation to a specific other are experiential and temporary, legacies of national representations and stereotypes - the "building blocks" of identity in particular situations - are more stable and less subject to change. In all, a wider framework of symbolic power relations and national identification allows to interpret how socio-historical legacies, myths and stereotypes inform the discursive formation of contemporary business manouvers.

The findings of the present study show that a post-colonial lens is particularly useful in understanding the "wider context" of (symbolic) power relations (cf. Prasad, 1997). As in the Swedish-Finnish setting, on the one hand, the colonizer continues to dominate the former colony, reproducing a sense of superiority through discursive acts of patronization, drawing upon discourse where the colonized is constructed as exotic and primitive, but familiar enough to be defined and governed (Prasad, 1997; Peltonen, 1999). On the other hand, the colony continues to reconstruct its identity as inferior through discursive acts of subjugation and by constantly positioning and comparing itself against the former colonizer. An asymmetric symbolic power structure is reproduced. It would be intriguing to explore contemporary British-French, German-French or British- German mergers or acquisitions in terms of national identity and power relations. These settings would probably reflect even more complex (re)constructions of identities and power as there is no self-evidently dominant symbolic national collective in the relationship. These relationships are yet loaded with proud nationalist sentiments due, in part, to the history of confrontation between the nations in question. The exchange of "compliments" between German and English tabloids in 1996, after Germany won the European Championship in football on England's home turf, is a banal example of this (Brookes, 1999). With similar rhetoric but less aggressively, a sense of German invasion was constructed in the UK media when the German BMW acquired the classic Rover brand. 
Finally, it seems to us that nationalism and national identities have remained a neglected topic for most organization and management scholars, be they mainstream or critical. Perhaps the subject is too obvious and self-evident to be taken seriously. Or, conversely, perhaps it is too sensitive a topic for members of dominant nations as it entails a particular form of selfreflection: that is, from the perspective of national identification, its basis and consequences. This would, however, in our view vitalize discussions on power. It would also deepen understandings of the role and influence of the media in the contemporary, apparently "global" world. We hope that ideas presented in this article - written from a geographical periphery in Europe - will encourage a revived interest. 


\section{References}

Anderson, Benedict (1983) Imagined communities: Reflections on the origin and spread of nationalism. London: Verso Editions and NLB.

Ashforth, Blake E. and Mael, Fred (1989) Social identity theory and the organization, Academy of Management Review, 14(4), 20-39.

Berglund, Johan and L"owstedt, Jan (1996) Sweden: The fate of human resource management in a "folkish" society, In: Timothy Clark (Ed.) European human resource management, Oxford: Blackwell.

Billig, Michael (1995) Banal nationalism, London: Sage.

Blain, Neil, Boyle, Raymond and O'Donnell, Hugh (1993) Sport and national identity in the European media, Leicester: Leicester University Press.

Bourdieu, Pierre (1998a) On television, New York: The New Press.

Bourdieu, Pierre (1998b) Acts of resistance - Against the new myths of our time, UK: Polity Press.

Boyle, Raymond and Haynes, Richard (1996) "The grand old game": Football, Media and identity in Scotland, Media, Culture and Society, 18, 549-64.

Brookes, Rod (1999) Newspapers and national identity: The BSE/CJD crisis and the British press, Media, Culture and Society, 21(2), 247-63.

Brown, Andrew D. (2001) Organization studies and identity: Towards a research agenda, Human Relations, 54(1), 113-21.

Bruun, Staffan and Mosse Wall'en (1999) Nokian valtatie, Helsinki: Tammi [Nokia's highway]. 
Buono, Anthony and Bowditch, J. L. (1989) The human side of mergers and acquisitions. Managing collisions between people, cultures, and organizations, San Francisco: Jossey-Bass.

Calori, Roland, Lubatkin, Mikael and Very, Phillipe (1994) Control mechanisms in crossborder acquisitions: An international comparison, Organization Studies, 15(3), 361-79.

Chomsky, Noam (1999) Profit over people - Neoliberalism and global order, New York: Seven Stories Press.

Clegg, Stewart (1989) Frameworks of power, London: Sage Publications.

Clegg, Stewart (1994) Power relations and the constitution of the resistant subject, In: J. M. Fernier, D. Knights and W. R. Nord (Eds.) Resistance and power in organizations, London: Routledge.

Czarniawska, Barbara (1997) Narrating the organization, Chicago: University of Chicago Press.

Davis, R. C. (1983) Lacan and narrative, Baltimore, MD: Johns Hopkins University Press.

De Cillia, Rudolf, Reisigl, Martin and Wodak, Ruth (1999) The discursive construction of national identities, Discourse and Society, 10(2), 149-73.

Ekwall, Anita and Karlsson, Svenolof (1999) Kohtaaminen Suomi-Ruotsi - kirja kulttuurieroista ja johtajuudesta, Vaasa, Finland: Storkamp Media [Meeting: Finland Sweden - A Book on cultural differences and management].

Fairclough, Norman (1995) Media discourse, London: Edward Arnold.

Fairclough, Norman (1997) Critical discourse analysis: The critical study of language (2nd ed.), London: Longman.

Fairclough, Norman (2000) Guest editorial: Language and neo-liberalism, Discourse and Society, 11(2), 147-8. 
Fiske, John (1989a) Understanding popular culture, London: Unwin Hyman.

Fiske, John (1989b) Reading the popular, London: Unwin Hyman.

Frommer, Ranja (2001) Between expectation and experience - An analysis of post-merger integration in two mergers, doctoral dissertation, The Royal Institute of Technology, Stockholm, Sweden.

Garfinkel, Harold (1967) Studies in ethnomethodology, Englewood Cliffs, NJ: Prentice Hall.

Gioia, Dennis and Chittipeddi, Kumar (1991) Sensemaking and sensegiving in a strategic initiation, Strategic Management Journal, 12(6), 433-48.

Grant, David, Keenoy, Tom and Oswick, Cliff (1998) Introduction. Organizational discourse: Of diversity, dichotomy and multi-disciplinarity, In: David Grant, Tom Keenoy and Cliff Oswick (Eds.) Discourse + organization, London: Sage.

Haspeslagh, Phillip and Jemison, David B. (1991) Managing acquisitions: Creating value through corporate renewal, Free Press, New York.

Hellgren, Bo, L“owstedt, Jan, Puttonen, Liisa, Tienari, Janne, Vaara, Eero and Werr, Andreas (2002) How issues become (re)constructed in the media: Discursive practices in the AstraZeneca merger, British Journal of Management, 13, 123.

Hirsch, Paul M. (1986) From ambushes to golden parachutes: Corporate takeovers as an instance of cultural framing and institutional integration, American Journal of Sociology, 91, $800-37$.

Laine-Sveiby, Kati (1987) Svenshet som strategi, Stockholm: Timbro [Swedishness as Strategy].

Laine-Sveiby, Kati (1991) Suomalaisuus strategiana, Porvoo, Finland: WSOY [Finnishness as Strategy]. 
Lubatkin, Michael, Calori, Roland, Very, Philippe and Veiga, John F. (1998) Managing mergers across borders: a two nation test of nationally bound administrative heritage, Organization Science, 9(6), 670-84.

Lyons, Evanthia and Breakwell, Glynis M. (1996) Changing European identities and social change in Europe: A challenge for social psychology, In: Glynis M. Breakwell and Evanthia Lyons (Eds.) Changing European identities: Social psychological analyses of social change, Oxford: Butterworth/Heinemann.

Mazza, Carmelo and Alvarez, Jose Luis (2000) Haute couture and pr`et-^a-porter: The popular press and the diffusion of management practices, Organization Studies, 21(3), 56788.

Nahavandi, A. and Malekzadeh, A. R. (1988) Acculturation in mergers and acquisitions, Academy of Management Review, 13, 79-90.

Olie, Ren'e (1994) Shades of culture and institutions in international mergers, Organization Studies, 15(3), 381-405.

Peltonen, Tuomo (1999) Colonial forces in "global" HRD: Finnish expatriates, developmental subjectivity and resistance, paper presented to the Critical Management Conference, UMIST, Manchester, UK, July.

Prasad, Anshuman (1997) The colonizing consciousness and representations of the other: A postcolonial critique of the discourse of oil, In: Pushkala Prasad, Albert J. Mills, M. Elmes and Anshu Prasad (Eds.) Managing the organizational melting pot: Dilemmas of workplace diversity, London: Sage.

Risberg, Anette (2001) Employee experiences of acquistion processes, Journal of World Business, 36(1), 58-84.

Said, Edward W. (1995) Orientalism, London: Penguin Books (first published 1978 by Routledge \& Kegan Paul). 
Schneider, Susan C. and Dunbar, Roger L. M. (1992) A psychoanalytic reading of hostile takeover events, Academy of Management Review, 17(3), 337-567.

S“antti, Risto (2001) How cultures interact in an international merger: Case Merita Nordbanken. University of Tampere, doctoral dissertation, Acta Universitasis Tamperensis 819.

Søderberg, Anne-Marie and Holden, Nigel (2002) Rethinking cross-cultural management in a globalising business world, International Journal of Cross-Cultural Management, 2(1), 10321.

Tajfel, Henri and Turner, J. C. (1979) An integrative theory of intergroup conflict, In: William G. Austin and Stephen

Worchel (Eds.) The Social Psychology of Intergroup Relations, Monterey: Brooks/Cole.

Thomas, Robyn and Linstead, Alison (2002) Losing the plot? Middle managers and identity, Organization, 8(1), 71-93.

Tienari, Janne (2000) Gender segregation in the making of a merger, Scandinavian Journal of Management, 16(2), 111-44.

Turner, J. C. (1985) Social categorization and the self-concept: A social cognitive theory of group behaviour, In: E. J. Lawler (Ed.) Advances in group processes: Theory and research (Vol. 2), Greenwich, CT: JAI Press.

Vaara, Eero (1999) Cultural differences and postmerger problems: misconceptions and cognitive simplifications, Nordiske Organisasjonsstudier (Nordic Organization Studies), 1, $59-88$.

Vaara, Eero (2002) On the discursive construction of success/failure in narratives of postmerger integration, Organization Studies, 23(2), 211-48. 
Vaara, Eero and Tienari, Janne (2002) Justification, legitimization and naturalization of mergers and acquisitions: A critical discourse analysis of media texts, Organization, 9, 275304.

Vaara, Eero, Tienari, Janne, S“ antti, Risto and Marschan-Piekkari, Rebecca (2000) Language as power in post-merger integration: The case of Merita-Nordbanken, competitive paper presented to the 26th Annual Conference of the European International Business Academy (EIBA), Maastricht, The Netherlands, December. Weick, Karl E. (1995) Sensemaking in organizations, Thousand Oaks: Sage.

Very, Philippe, Lubatkin, Michael and Calori, Roland (1998) A cross-national assessment of acculturative stress in recent European mergers, In: Martina C. Gertsen, Anne-Marie Søderberg and J. E. Torp (Eds.) Cultural dimensions of international mergers and acquisitions, Berlin: Walter de Gruyter.

Zander, Lena (1999) Management in Sweden, In: Malcolm Warner and Pat Joynt (Eds.) Management in Europe, UK: Thomson Learning Business Press. 